\title{
Correction to: Substrate utilization and energy expenditure pattern in sepsis by indirect calorimetry
}

Andrew $\mathrm{Li}^{1,2^{*}}$ (D) and Amartya Mukhopadhyay ${ }^{1,2,3}$

\section{Correction to: Critical Care (2020) 24:535 https://doi.org/10.1186/s13054-020-03245 $-2$}

Following publication of the original article [1], the authors reported a misalignment error of the $\mathrm{x}$-axis in Fig. 1b; in addition, there were two typos and two formatting errors. The revised Fig. $1 \mathrm{~b}$ and revised text is indicated hereafter. The changes have been highlighted in bold typeface.

The sentence currently reads:

The metabolic profiles differed between survivors and non-survivors (Fig. 1a). Both groups had negative energy balance during fasting state. Survivors transitioned to a hypermetabolic state following feeding initiation, achieving positive energy balance. Non-survivors remained hypometabolic despite feeding.

The sentence should read:

The metabolic profiles differed between survivors and non-survivors (Fig. 1a). Both groups had negative energy balance during fasting state. Survivors transitioned to a hypermetabolic state following feeding initiation,

The original article can be found online at https://doi.org/10.1186/s1305 4-020-03245-2

*Correspondence: Andrew_yunkai_li@nuhs.edu.sg

1 Yong Loo Lin School of Medicine, National University of Singapore, Singapore, Singapore

Full list of author information is available at the end of the article achieving positive energy balance. Non-survivors remained hypometabolic despite feeding.

The sentence currently reads:

Our study advances the understanding of energy balance and substrate utilization in sepsis. During fasting, low insulin with elevated counter-regulatory hormones promotes lipolysis; muscle glycogen is depleted at an exponential rate greater than athletes running marathons [4]. The predominant energy substrate switches from carbohydrates to lipids - the hallmark of fasting physiology. This explains the low RQ in early sepsis, when patients are preferentially utilizing lipids $(\mathrm{RQ} \leq 0.8)$ during permissive underfeeding [5]. The hypermetabolic state and inability for non-survivors to transit to carbohydrate utilization suggest ongoing debilitating mitochondrial dysfunction, consistent with associated multi-organ failure [6]. However, whether adjusting the feeding types and regimen to alter these patterns and improve outcomes remain unknown.

The sentence should read:

Our study advances the understanding of energy balance and substrate utilization in sepsis. During fasting, low insulin with elevated counter-regulatory hormones promotes lipolysis; muscle glycogen is depleted at an exponential rate greater than athletes running marathons [4]. The predominant energy substrate switches from carbohydrates to lipids - the hallmark of fasting physiology. This explains the low RQ in early sepsis, when patients original author(s) and the source, provide a link to the Creative Commons licence, and indicate if changes were made. The images or other third party material in this article are included in the article's Creative Commons licence, unless indicated otherwise in a credit line to the material. If material is not included in the article's Creative Commons licence and your intended use is not permitted by statutory regulation or exceeds the permitted use, you will need to obtain permission directly from the copyright holder. To view a copy of this licence, visit http://creativecommons.org/licenses/by/4.0/. The Creative Commons Public Domain Dedication waiver (http://creativeco mmons.org/publicdomain/zero/1.0/) applies to the data made available in this article, unless otherwise stated in a credit line to the data. 


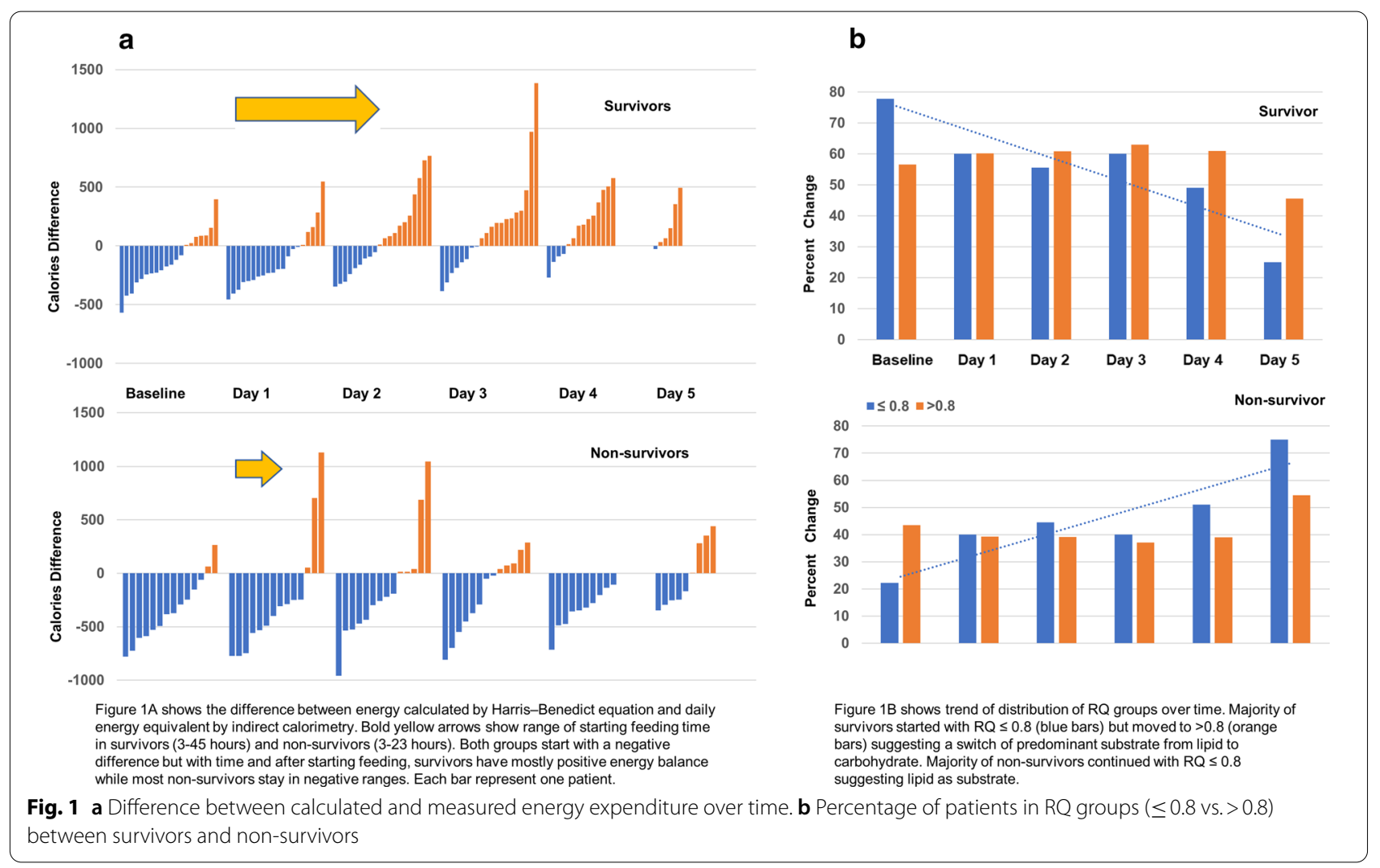

are preferentially utilizing lipids $(\mathrm{RQ} \leq 0.8)$ during relative underfeeding [5]. The hypometabolic state and inability for non-survivors to transit to carbohydrate utilization suggest on-going debilitating mitochondrial dysfunction, consistent with associated multi-organ failure [6]. However, whether adjusting the feeding types and regimen to alter these patterns to improve outcomes remain unknown.

This has now been included in this correction article.

\section{Author details}

${ }^{1}$ Yong Loo Lin School of Medicine, National University of Singapore,

Singapore, Singapore. ${ }^{2}$ Division of Respiratory and Critical Care Medicine, Department of Medicine, National University Hospital, Singapore, Singapore.

${ }^{3}$ Medical Affairs, Alexandra Hospital, Singapore, Singapore.

Published online: 24 November 2020

\section{References}

1. Li A, Mukhopadhyay A. Substrate utilization and energy expenditure pattern in sepsis by indirect calorimetry. Crit Care. 2020;24:535. https://doi. org/10.1186/s13054-020-03245-2.

4. Wischmeyer PE, San-Millan I. Winning the war against ICU-acquired weakness: new innovations in nutrition and exercise physiology. Crit Care. 2015;19(Suppl 3):S6.

5. Arabi YM, Aldawood AS, Haddad SH, Al-Dorzi HM, Tamim HM, Jones G, et al. Permissive underfeeding or standard enteral feeding in critically ill adults. N Engl J Med. 2015;372:2398-408.

6. Leverve XM. Mitochondrial function and substrate availability. Crit Care Med. 2007;35(9 Suppl):\$454-60.

\section{Publisher's Note}

Springer Nature remains neutral with regard to jurisdictional claims in published maps and institutional affiliations.

Ready to submit your research? Choose BMC and benefit from:

- fast, convenient online submission

- thorough peer review by experienced researchers in your field

- rapid publication on acceptance

- support for research data, including large and complex data types

- gold Open Access which fosters wider collaboration and increased citations

- maximum visibility for your research: over $100 \mathrm{M}$ website views per year

At BMC, research is always in progress.

Learn more biomedcentral.com/submissions 